International Journal of Engineering \& Technology, $7(4.34)(2018) 7-10$
International Journal of Engineering \& Technology
SPC
Website: www.sciencepubco.com/index.php/IJET
Research paper

\title{
Emotional Intelligence and the Big Five Personality Model of Higher Learning Institutions
}

\author{
Noorazzila Shamsuddin", Aziz Amin²*, Nik Sarina Nik Md Salleh ${ }^{1}$ \\ ${ }^{1}$ Universiti Teknologi MARA, Kelantan, Malaysia \\ ${ }^{2}$ Faculty of Applied Social Sciences, Universiti Sultan Zainal Abidin, Terengganu, Malaysia \\ *Corresponding author E-mail: wanazizmn@unisza.edu.my
}

\begin{abstract}
In today's educational environment, especially in institutions of higher learning, the responsibility of lecturers is not solely restricted to teaching and improving the knowledge of students in the classroom, but in fact requires more than that. Academic staffs need strong work ethic and good personality in order to be as a good role model for students. Lecturers, educators, teachers or whatever the term used to call them, is a contributor to the organization's development and excellence. Job descriptions are not only focused on formal job assignments such as lectures, but also require lecturers, for example, to engage in various types of collaboration and help other stakeholders in the organization. In addition, lecturers need to support the social and organizational psychology context and this can be done through organizational citizenship behavior (OCB).
\end{abstract}

Keywords: Organisational citizenship behavior; emotional intelligence and Big Five personality traits.

\section{Introduction}

Malaysia Education Blueprint 2015-2025 [1] has emphasized the education system in Malaysia needs to transform from system that focused on the inputs and difference between private and public institutions towards a harmonized higher education system. It also requires the higher education system to give more focus on delivery, accountability, transparency and outcomes. The academic community has become the main focus during this transformation journey. In relation with organizational citizenship behavior (OCB), a study by [2] found that academic staff as employees in an institution, their committed behavior is critical to ensure the institutions to be functioned more effective. Moreover, the researchers also suggest that if the academic staff lack in OCB it can affect the academic performance of the students and the success of the organization. In [3] discovered that one of the way to increase OCB and reduce counterproductive work behaviors among employee is through developing their emotions which is emotional intelligence (EI) so that it can help to stimulate the positive emotions of employees. In addition of emotional intelligence, personality also has significant effect towards organizational citizenship behavior. The study by [4] examined the Big Five Personality Traits on OCB and the author found that all personality traits had effects on OCB. Furthermore, in [5] proposed if individual had better personality it will lead to better OCB.

\section{Literature review}

\subsection{Emotional intelligence}

In [6] defined emotion as an organized response to an event, externally or internally that positively or negatively affects the biology meaning of an individual. In [7] also indicates emotional intelli- gence as the capability to recognize own and other feelings to motivate one-self and properly manage the emotions in a relationship. A study by [8] describes that individuals that have the capacity to be aware of, regulate and utilize their own emotions and others' emotion are actually possess emotional intelligence, and this is considered as one of the factor for job performance. Consequently, it will positively correlate to the successful individual outcomes in organization. In [9] found that emotional intelligence plays important roles in Malaysia's working environment. In order to sustain competitive advantage, Malaysia needs strong and efficient workforces who constantly practice unrestricted behavior that surpass their formal role requirements and improve the overall functioning of the organizations.

There have several studies been related in developing the models of emotional intelligence. For instance, in [10] has developed the ability-based model of emotional intelligence that consist of four major areas which reflectively regulating emotions, understanding emotions, assimilating emotions in thoughts and perceiving and expressing emotions. Another study by [11] proposed the most recent version of competency-based model of emotional intelligence that consist of four major clusters which self-awareness, self-management, social awareness and relationship management. In [12] had developed a self-report emotional intelligence scale that consists of self-emotion appraisal (SEA), others' emotion appraisal (OEA), regulation of emotion (ROE) and use of emotion (UOE) that relates to the use of emotion to facilitate performance. Some of the models had been tested in various studies including organizational citizenship behavior (OCB).

\subsubsection{Self-emotion appraisal (SEA)}

SEA is termed as the appraisal and expression of emotion in one self [12]. In a study by [13], they discovered that when teachers in school are aware of their own emotions, it shows they have higher SEA and be able to teach the students in a more effective manner. 
Furthermore, in [14] found that their respondents in their study realize the importance of having the knowledge of SEA especially if they were under stress because by stress can prevent them from being able to fully engage and achieve desirable results in their work.

\subsubsection{Others' emotion appraisal (OEA)}

In [15] describes individuals with OEA have the high ability to understand emotions of others and will be more motivated to interact with others. This dimension of emotional intelligence is related with appraisal and recognition of emotion in others [12]. In a study by [16], the researchers found that the ability of understanding others' emotions is important when determining the level of trust to be given to other co-workers at work.

\subsubsection{Regulation of emotion (ROE)}

According to [12], ROE focuses on the regulation of emotion in oneself. Therefore, in [17] emphasizes that individuals with ROE focus more on how to manage their own emotions in the most appropriate way. In addition, ROE also helps to encourage cooperation, interpersonal sensitivity and helping co-workers in accomplishing the organizational goals [18].

\subsubsection{Use of emotion (UOE)}

UOE is referred as the use of emotion to facilitate performance [12]. Following [19], UOE had greater influence on OCB compare to SEA whereby UOE can lead in creating positive working environment. Moreover, a research study by [20] also confirmed that if individuals have the ability to use own emotion effectively, it will lead them to help others and encouraging the altruistic behavior of OCB.

\subsection{Personality}

\subsubsection{Extraversion}

According to [21], people who portray agreeableness traits are those who the value of cooperation and priorities for positive interpersonal relationships. Also a person who has a high end of agreeableness is bound to fear. In [22] has described extraversion as key dispositional determinant of social behavior, thus those who are highly extraverted display more flexible behaviors that make them more likely to show OCB.

\subsubsection{Agreeableness}

Agreeableness or sociability refers to friendly, considerate and modest behavior [23]. People who score high on this dimension tend to have an optimistic view that most people around them are honest, decent, and trustworthy. According to [24], the agreeable employees usually will show higher levels of interpersonal competence and also collaborate effectively when joint action is needed [25].

\subsubsection{Conscientiousness}

Conscientiousness indicates an individual's degree of organization, persistence, hard work, and motivation in the pursuit of goal accomplishment [21]. Someone who has this trait prefers to conform to rules and regulations, and is reliable. However, individuals who are low on conscientiousness tend to be more laid back, less goal oriented, and less driven by success. Conscientious individuals are dependable, efficient, and hardworking. They are predisposed to take advantage in solving problems and are more methodical and detailed or thorough in their work [24]. In addition, conscientious individuals will carry out in-role behaviors (i.e., individual task performance) well beyond the minimum required levels [26].

\subsubsection{Neuroticism}

It is the number and strength of stimuli required to elicit negative emotions in a person [27]. Typical behaviors associated with these factors include anxiety, depression, anger, shame, emotional, fear, and insecurity. According to [28], neuroticism has negative effect on students' conditional value and students with less neurotic are more emotionally stable and less reaction toward stress.

\subsubsection{Openness to experiences}

By referring to [29], desire to learn among these individuals high in intellect may result in their tendency to explore and gain knowledge from sincere work. Importantly, individuals high on openness to experience display a preference for variety, they enjoy grasping new ideas, and they have an intrinsic interest in and appreciation for novelty [30].

\subsection{Organizational citizenship behaviour (OCB)}

Dennis Organ first introduced organizational citizenship behaviour (OCB) in the mid-1980s and this theory had been expanded with linkage to various other fields over years [31]. In [32] indicates the OCB is important for the survival of an organization whereby OCB can maximize the efficiency and productivity of both employee and organization so that they can be function more effectively. Besides, in [33] stated that OCB illustrate the actions of employees willing to do that sometimes beyond their original role requirements and it also type of socially desirable class of behavior. A study by [34] had identified five categories of OCB. First, altruism that relates to behavior of helping of an individual co-worker on task. Second, courtesy, behavior of alerting other worker in organization about changes that may affect their work. Third, conscientiousness behavior in carrying out one's duties beyond the minimum requirements. Fourth, sportsmanship which behavior of refraining from complaining about trivial matters and lastly civic virtue that refer to behavior of participating in the governance of the organization. In [35] reported that civic virtue can improve the enterprise resource planning (ERP) information system. Besides, courtesy and altruism are also very crucial in the application of ERP.

\subsection{Emotional intelligence, big five personalities and OCB}

Based on study conducted by [36] the researchers discovered there was significant relationship between EI and OCB with three of the EI dimension (others' emotional appraisal, use of emotion and regulation of emotion) were statically significant related to OCB. In addition, emotional intelligence also had positive influence towards OCB because employee with high level of emotional intelligence had better understanding about their own feeling and able to respond better to co-workers with low level of emotional intelligence [37]. Many studies had found relation of big five personality traits with OCB. In [38] discovered that agreeableness, consciousness and openness have the greatest effect towards $\mathrm{OCB}$ of the university staff. In [39] also discovered individual with extraversion traits was expected to help others at workplace and take active role in solving the organizational problem compared to individual with introvert traits. Besides, in [40] reported that agreeableness and extraversion were significantly related with dimensions in OCB. In contrast, the study by [41] failed to find a strong relation between OCB and agreeableness because it seems that elements in extraversion actually have greater impact towards OCB compare to element in agreeableness.

\section{Conceptual Framework}

Fig. 1 depicts the proposed conceptual framework that comprises two different variables which are independent and dependent. The first part of the framework is emotional intelligence (self-emotion 
appraisal, others' emotion appraisal, regulation of emotion and use of emotion. The second part is big five personality traits (extraversion, agreeableness, conscientiousness, neuroticism and openness to experiences). For the third part, it is organizational citizenship behavior.

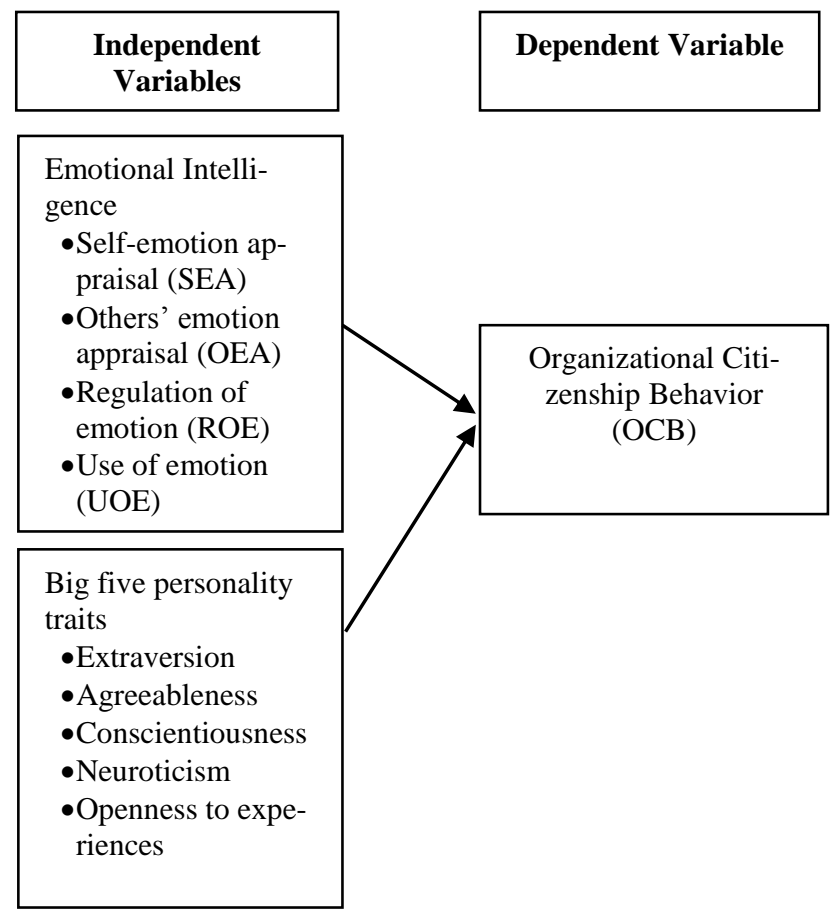

Fig. 1: The conceptual framework

Based on the above framework, several hypotheses have been developed:

$\mathrm{H}_{1}$ a) Self-emotional appraisal (SEA) has significant relationship with organizational citizenship behaviour (OCB).

$\mathrm{H}_{1}$ b) Other's emotion appraisal (OEA) has significant relationship with organizational citizenship behaviour (OCB).

$\left.\mathrm{H}_{1} \mathrm{c}\right)$ Use of emotion (UOE) has significant relationship with organizational citizenship behaviour (OCB).

$\mathrm{H}_{1}$ d) Regulation of emotion (ROE) has significant relationship with organizational citizenship behaviour (OCB).

$\mathrm{H}_{2}$ a) Extraversion has significant relationship with organizational citizenship behaviour (OCB).

$\mathrm{H}_{2}$ b) Agreeableness has significant relationship with organizational citizenship behaviour (OCB).

$\mathrm{H}_{2} \mathrm{c}$ ) Conscientiousness has significant relationship with organizational citizenship behaviour (OCB).

$\mathrm{H}_{2}$ d) Neuroticism has significant relationship with organizational citizenship behaviour (OCB).

$\left.\mathrm{H}_{2} \mathrm{e}\right)$ Openness to experiences has significant relationship with organizational citizenship behaviour (OCB).

\section{Conclusion}

This paper was intended to discuss about the relationships between emotional intelligence and big five personalities towards organizational citizenship behaviour, especially in higher learning institutions. The hypotheses have been developed and are expected to measure the direction of this relationship.

\section{Acknowledgement}

The authors would like to thank the Research Management, Innovation and Commercialization Centre, Universiti Sultan Zainal Abidin, Terengganu, Malaysia for providing the financial assistance to support the publication fee of this article. Special thanks are extended to the Management of UiTM and team members for their unconditional support to complete this article.

\section{References}

[1] Ministry of Higher Education (MOHE) (2015), Malaysia Education Blueprint 2015-2025 (Higher Education). www.mohe.gov.my/muat-turun/awam/penerbitan/pppm-2015-2025$\mathrm{pt} / 5$-malaysia-education-blueprint-2015-2025-higher-education.

[2] Cheasakul U and Varma P (2016), The influence of passion and empowerment on organizational citizenship behavior of teachers mediated by organizational commitment. Contaduría y Administración 61,422-440.

[3] Kwasi D and Benjamin M (2017), The leaders' emotional intelligence: An antecedent of employees' voluntary workplace behaviour. Evidence from the Ghanaian banking sector. African Journal of Economic and Management Studies 8(3), 352-365.

[4] Leephaijaroen S (2016), Effects of the big-five personality traits and organizational commitments on organizational citizenship behavior of support staff at Ubon Ratchathani Rajabhat University, Thailand. Kasetsart Journal of Social Sciences 37, 104-111.

[5] Sri I, Solimun, Adji ARF and Wardhani H (2017), The effect of OCB in relationship between personality, organizational commitment and job satisfaction on performance. Journal of Management Development 36(10), 1283-1293.

[6] Mayer JD, DiPaolo M and Salovey P (1990), Perceiving affective content in ambiguous visual stimuli: A component of emotional intelligence. Journal of Personality Assessment, 54(3\&4), 772-781.

[7] Goleman D (2000), An EI-based theory of performance. In D Goleman, \& C. Cherniss (Eds.), The Emotionally Intelligent Workplace: How to Select for, Measure, and Improve Emotional Intelligence in Individuals, Groups, and Organizations. California: Jossey-Bass, pp. 27-44

[8] Wu YC (2011), Job stress and job performance among employees in the Taiwanese finance sector: The role of emotional intelligence. Social Behavior and Personality 39(1), 21-23.

[9] Noorlaila Y (2012), Displaying employees' organizational citizenship behaviour: The impact of emotional intelligence and leader-member exchange in development bank in Malaysia. International Journal of Social Science and Humanity 2(4), 344-349.

[10] Mayer JD, Caruso DR and Salovey, P (1999), Emotional intelligence meets traditional standards for an intelligence. Intelligence 27(4), 267-298.

[11] Goleman D (2000), An EI-based theory of performance. In D. Goleman, \& C. Cherniss (Eds.), The Emotionally Intelligent Workplace: How to Select for, Measure, and Improve Emotional Intelligence in Individuals, Groups, and Organizations. California: Jossey-Bass, pp. 27-44.

[12] Wong CS and Law KS (2002), The effects of leader and follower emotional intelligence on performance and attitude: An exploratory study. The Leadership Quarterly 13, 243-274.

[13] Alam, A and Ahmad, M (2018), The role of teachers' emotional intelligence in enhancing student achievement. Journal of Asia Business Studies 12(1), 31-43.

[14] Potter EM, Egbelakin T, Phipps R and Balaei B (2018), Emotional intelligence and transformational leadership behaviours of construction project managers. Journal of Financial Management of Property and Construction 23(1), 73-89.

[15] Yohanes S, Kohar S and Fauziah E (2016), Developing Organization Citizenship Behavior of Employees in the Hospitality Industry through Organizational Culture, Emotional Intelligence and Work Motivation. International Journal of Science and Technology 5(11), 567-578.

[16] Christie AM, Jordan PJ and Troth AC (2015), Trust antecedents: Emotional intelligence and perceptions of others. International Journal of Organizational Analysis 23(1), 89-101.

[17] Dartey-Baah K and Mekpor B (2017), The leaders' emotional intelligence: An antecedent of employees' voluntary workplace behaviour. Evidence from the Ghanaian banking sector. African Journal of Economic and Management Studies 8(3), 352-365.

[18] Pradhan RK, Jena LK and Singh SK (2017). Examining the role of emotional intelligence between organizational learning and adaptive performance in Indian manufacturing industries. Journal of Workplace Learning 29(3), 235-247.

[19] Jung HS and Yoon HH (2012), The effects of emotional intelligence on counterproductive work behaviors and organizational citizen behaviors among food and beverage employees in a deluxe hotel. International Journal of Hospitality Management 31(2), 369-378. 
[20] Anwar MA, Osman-Gani AM, Fontaine R and Rahman MS (2017), Assessing organizational citizenship behaviour through constructing emotional intelligence. Asia-Pacific Journal of Business Administration 9(2), 105-117.

[21] Zhao $H$ and Seibert SE (2006). The Big Five personality dimensions and entrepreneurial status: A meta-analytical review. Journal of Applied Psychology 91(2), 259-271.

[22] Barrick MR, Parks L and Mount MK (2005), Self-monitoring as a moderator of the relationships between personality traits and performance. Personnel Psychology 58(3),745-767.

[23] Furnham A and Christoforou I (2007), Personality Traits, Emotional Intelligence, and Multiple Happiness. North American Journal of Psychology 9(3), 439-462.

[24] Witt LA, Burke LA, Barrick MR, Mount MK (2002), The interactive effects of conscientiousness and agreeableness on job performance. Journal of Applied Psychology 87(1), 164-169.

[25] Mount MK, Barrick MR, Stewart GL (1998), Five-factor model of personality and performance in jobs involving interpersonal interactions. Human Performance 11(2-3), 145-165.

[26] Koys DJ (2001), The effects of employee satisfaction, organizational citizenship behavior, and turnover on organizational effectiveness: A unit-level, longitudinal study. Personnel Psychology 54(1), 101-114.

[27] Barrick MR and Mount MK (1991), The big five personality dimensions and job performance: a meta-analysis. Personnel Psychology 44(1), 1-26.

[28] Watjatrakul B (2016), Online learning adoption: Effects of neuroticism, openness to experience, and perceived values. Interactive Technology and Smart Education 13(3), 229-243.

[29] Szabo A and Underwood J (2004), Cybercheats: Is information and communication technology fuelling academic dishonesty? Active Learning in Higher Education 5(2), 180-199.

[30] McCrae RR and John OP (1992), An introduction to the five-factor model and its applications. Journal of Personality 60(2), 175-215.

[31] Farh JL, Zhong CB and Organ DW (2004), Organizational citizenship behavior in the People's Republic of China. Organization Science 15(2), 241-253.

[32] Jahangir N, Mohammad MA and Mahmudul H (2004), Organizational citizenship behaviour: Its nature and antecedents. BRAC Univesity Journal 1(2), 75-85.

[33] Chien MH (2003), A study to improve organizational citizenship behaviors. Proceedings of the International Congress on Modelling and Simulation, pp. 1364-1367.

[34] Jung HS and Yoon HH (2012), The effects of emotional intelligence on counterproductive work behaviors and organizational citizen behaviors among food and beverage employees in a deluxe hotel. International Journal of Hospitality Management 31(2), 369-378.

[35] Narimani M, Tabaeian E, Khanjani M and Soltani F. (2013), The impact of organizational citizenship behavior on enterprise resource planning success: The mediator role of TQM. International Journal of Quality and Reliability Management 31(1), 53-65.

[36] Md. Aftab A, Aahad MO, Rodrigue F and Muhammad SR (2017), Assessing organizational citizenship behaviour through constructing emotional intelligence. Asia-Pacific Journal of Business Administration 9(2), 105-117.

[37] Jain AK and Cooper CL (2012), Stress and organisational citizenship behaviours in Indian business process outsourcing organisations. IIMB Management Review 24(3), 155-163.

[38] Mahdiuon R, Ghahramani M and Sharif AR (2010), Explanation of organizational citizenship behavior with personality. ProcediaSocial and Behavioral Sciences 5, 178-184.

[39] Purba DE, Oostrom JK, Van Der Molen HT and Born MP (2015), Personality and organizational citizenship behavior in Indonesia: The mediating effect of affective commitment. Asian Business and Management 14(2), 147-170.

[40] Kiffin-Petersen SA, Jordan CL and Soutar GN (2011), The big five, emotional exhaustion and citizenship behaviors in service settings. The mediating role of emotional labor. Personality and Individual Differences 50(1), 43-48.

[41] Helle AC, DeShong HL, Lengel GJ, Meyer NA, Butler J and Mullins-Sweatt SN (2018), Utilizing Five Factor Model facets to conceptualize counterproductive, unethical, and organizational citizenship workplace behaviors. Personality and Individual Differences 135, 113-120. 